\title{
Analisis Miskonsepsi Mahasiswa pada Empat Konsep Esensial Kesetimbangan Kimia
}

\author{
Muti'ah \\ Program Studi Pendidikan Kimia FKIP Unram \\ Jalan Majapahit No.62 Mataram 83125
}

\begin{abstract}
Abstrak : Telah dilakukan penelitian tentang analisis miskonsepsi mahasiswa pada empat aspek esensial pada kesetimbangan kimia. Subyek dalam penelitian ini adalah Mahasiswa semester pertama Program Studi Pendidikan Kimia FKIP Unram. Pengambilan data dilakukan dengan memberikan tes tentang kesetim-bangan kimia yang memuat empat aspek, yaitu stoikhiometri, tetapan kesetimbangan, kesetimbangan yang melibatkan hukum gas ideal, dan pergeseran kesetimbangan/ prinsip Le Chatelier's pada sistem kesetimbangan heterogen. Berdasarkan analisis miskonsepsi mahasiswa pada empat aspek esensial kesetimbangan kimia, yaitu: konsep mol dan stoikhiometri (30,10\%), tetapan kesetimbangan (22,85\%), konsep kesetimbangan yang melibatkan gas ideal (78,55\%) dan pada konsep pergeseran kestimbangan/ prinsip Le Chatelier's pada reaksi heterogen (70,78\%). Miskonsepsi pada aspek stoikhiometri terutama adalah kegagalan dalam mengkonversi hubungan gram-mol-liter (14,3\%), perhitungan zat-zat yang terlibat dalam reaksi (28,6\%) dan mengidentifikasi pereaksi berlebih (71,4\%). Miskonsepsi pada aspek tetapan kesetimbangan adalah pernyataan persamaan Kc (17,1\%), penggunaan satuan mol dalam menghitung nilai Kc (28,6\%). Miskonsepsi pada aspek kesetimbangan yang melibatkan gas ideal adalah kegagalan dalam menghitung jumlah mol berdasarkan persamaan gas ideal $P V=n R T$ (82,9\%), dan mengartikan hukum tersebut (74,2\%). Miskonsepsi pada aspek pergeseran kesetimbangan/prinsip Le Chatelier's adalah melibatkan zat padat pada perhitungan Kc $(57,1 \%)$, pengaruh zat padat pada kesetimbangan (82,8\%), pengaruh gas $\mathrm{NH}_{3}(68,6 \%)$, dan pengaruh gas inert $\mathrm{N}_{2}$ padfa V,T tetap sebesar $80 \%$. Dari hasil penelitian ini dapat disimpulkan bahwa miskonsepsi mahasiswa dalam memahami topik kesetimbangan kimia adalah aspek prinsip Le Chatelier, reaksi kesetimbangan yang melibatkan gas ideal, stoikhiometri dan tetapan Kc
\end{abstract}

Kata kunci : Miskonsepsi mahasiswa,empat topik esensial, kesetimbangan kimia

Analysis of Students’ Misconception in Four Essential Concepts of Chemical Equilibrium

\begin{abstract}
The research related with analysis of students' misconception on four essential aspects on the chemical equilibrium has been conducted. The subjects of the study were first-semester students of Study Program Chemical Education, FKIP Program Unram. Data is collected using the test associated with chemical equilibrium that includes four aspects, particularly stoichiometry, the equilibrium constant, the equilibrium reactions involving ideal gas law, and equilibrium shift/ Le Chatelier's principle in heterogeneous equilibrium systems.

From the analysis of data are found students' misconceptions in the four aspects are: the mol concept and stoichiometry mol (30.10\%), the equilibrium constant (22.85\%), the equilibrium which involves the ideal gas law (78.55\%) and the concept of equilibrium shift/Le Chatelier's principle in heterogeneous equilibrium reactions (70.78\%). Misconceptions on stoichiometry aspect particularly in converting in a gram-mol-liter (14.3\%), the calculation of the substances involved in the reaction (28.6\%) and identified the excess reagent $(71.4 \%)$. Misconceptions on equilibrium constant aspect is a statement of the Kc equation (17.1\%), the use of moles unit in calculating the value of Kc (28.6\%). Misconceptions on aspect of equilibrium reactions involving ideal gas law is failure to calculate the moles number based ideal gas equation $\mathrm{PV}=\mathrm{nRT}(82.9 \%)$, and interpret this law (74.2\%). Misconceptions at aspects of the equilibrium shift/Le Chatelier's principle involves the solid phase in the calculation of $\mathrm{Kc}$ (57.1\%), effect of the solid phase at equilibrium (82.8\%), effect $\mathrm{NH}_{3}$ gas (68.6\%), and effect inert gas $\mathrm{N}_{2}$ at $\mathrm{V}$, T constant is $80 \%$. Misconceptions on aspect of equilibrium reactions involving ideal gas law is failure to calculate the moles number based equation state of ideal gas $\mathrm{PV}=\mathrm{nRT}(82.9 \%)$, and interpret this law (74.2\%). Misconceptions in the equilibrium shift/Le Chatelier's principle aspect involves the solid phase in the calculation of $\mathrm{Kc}$ (57.1\%), effect of the solid phase at equilibrium (82.8\%), effect of $\mathrm{NH}_{3}$ gas (68.6\%), and effect of inert gas $\mathrm{N}_{2}$ on $\mathrm{V}$, T constant is $80 \%$. Result of this research can be concluded that the misconceptions of students in understanding the topic of chemical equilibrium are aspects of Le Chatelier's principle, equilibrium reactions involving the ideal gas, stoichiometry, and Kc equation.
\end{abstract}

Keywords : student's misconception, four essential topic, chemical equilibrium 


\section{I.PENDAHULUAN}

Selama tiga dekade terakhir berbagai peneliti telah melakukan penelitian tentang adanya miskonsepsi/ konsepsi alternatif siswa yang diperoleh melalui penafsiran dan keyakinan sendiri [1]. Miskonsepsi atau konsepsi alternatif merupakan konsep yang dimiliki siswa, tetapi bertentangan dengan hasil konsensus ilmiah. Konsep tersebut merupakan konsep baru yang dikembangkan berdasarkan penafsiran, sesuai dengan ide-ide yang ada dan keyakinan siswa [2]

Beberapa sumber miskonsepsi adalah: adanya kata-kata yang berbeda dengan apa yang ditemui dalam kehidupan sehari-hari [3], kompetensi guru dan ketidaksesuaian antara pemahaman guru dan siswa [4], simbol kimia yang telah diubah makana oleh siswa dan buku pelajaran [5]

Topik kesetimbangan kimia merupakan bagian esensial dalam kimia, karena mendasari konsep kimia lanjut misalnya kesetimbangan larutan, kesetimbangan fasa, dan kesetimbangan reaksi sel elektrokimia [6]. Namun demikian dari hasil pengalaman selama mengajar di Progdi. Pendidikan Kimia FKIP Unram, menunjukkan adanya kesulitan mahasiswa dalam memahami konsep tersebut yang ditunjukkan oleh rendahnya nilai tes hasil belajar dengan nilai rata-rata di bawah 6 . Hal tersebut menunjukkan masih adanya miskonsepsi yang terdapat pada siswa/mahasiswa.

Miskonsepsi siswa dalam memahami topik kesetimbangan kimia telah dilaporkan oleh peneliti terdahulu [6]. Secara umum peneliti tersebut menyimpulkan bahwa meskonsepsi siswa disebabkan konsep tersebut bersifat abstrak dan mengandung kata-kata yang memiliki arti ganda. Qulilez-Pardo dan Solaz-Portoles melaporkan bahwa kesalahan konsep siswa terutama adalah dalam memahami pergeseran kesetimbangan [7]. Menurut Huddle dan Pillay kesalahan konsep siswa terutama disebabkan oleh tidak menguasainya konsep mol dan konsentrasi, konsentrasi zat saat setimbang, dan kesulitan dalam memahami prinsip Le Catelier [8]

Perkembangan selanjutnya Tyson dan kawankawan menitik beratkan pada prinsip Le Chaterlier dari aspek kualitatif dan hukum kesetimbangan [9]. Furio dan kawan-kawan menitik beratkan pada prinsip Le Chatelier dari aspek kuantitatif dan kesetimbangn heterogen [5]. Selanjutnya Kousathana dan Tsaparlis melakukan analisis kesalahan konsep siswa pada aspek konstanta kesetimbangan dan stoikhiometri [10]

Miskonsepsi pada siswa berpengaruh pada pembelajaran kimia, bukan hanya memberi jawaban yang salah dalam menjawab suatu pertanyaan, tetapi baik secara sadar maupun tidak sadar siswa akan membangun konsep untuk menjelaskan sifat atau teori sesuai yang mereka alami [5]. Siswa yang demikian akan merasa benar dengan konsep yang dimiliki, karena diperoleh berdasarkan pengalaman sendiri. Akibatnya, jika mendapat informasi baru yang bertentangan dengan konsep yang dimiliki maka akan sulit diterima karena dianggap salah [11]

Selanjutnya Camacho dan Good menyatakan bahwa seorang siswa yang memiliki kesalahan konsep biasanya sulit diperbaiki, sehingga diperlukan strategi/ metode pembelajaran khusus untuk mengatasisnya [12]. Selain itu, seorang siswa yang mengalami miskonsepsi dapat menghambat pada pembelajaran berikutnya

Sehubungan dengan hal tersebut di atas pemahaman siswa/mahasiswa Progdi. Pend. Kimia pada konsep kesetimbangan kimia masih rendah atau masih terdapat miskonsepsi. Oleh sebab itu diperlukan strategi/ metode pembelajaran yang tepat untuk memperbaikinya. Untuk dapat memilih metode yang tepat diperlukan suatu diagnosis yang tepat terhadap masalah tersebut. Diagnosis yang tepat dapat dilakukan dengan melakukan analisis jawaban siswa tentang konsep esensial dalam topik kesetimbangan kimia.

Menurut Kousathana dan Tsaparlis, konsep esensisal dalam kesetimbangan kimia adalah: mol dan stoikhiometri, konsentrasi dan tetapan kesetimbangan, prinsip Le Chatelier's, dan reaksi fasa gas dan hukum gas ideal [10]. Sejauh penelusuran putakan yang ada, sampai saat ini publikasi mengenai analisis miskonsepsi mahasiswa pada topik esensial kesetimbangan kimia secara lengkap masing jarang ditemui. Oleh sebab itu penelitian tentang analisis kesalahan konsep/miskonsepsi mahasiswa pada topik kesetimbangan kimia perlu dilakukan.

Tujuan dari penelitian ini adalah teridentifikasinya miskonsepsi/kesalahan konsep mahasiswa dalam memahami konsep esensial kesetimbangan kimia (mol dan stoikhiometri, konsentrasi dan tetapan kesetimbangan, prinsip Le Chatelier's, dan reaksi fasa gas dan hukum gas ideal. Manfaat yang diperoleh dari penelitian ini adalah dapat dijadikan dasar dalam penetapan strategi dan metode pembelajaran yang tepat dan spesisfik dalam dapat memperbaiki kesalahan konsep siswa sehingga dapat meningkatkan kualitas pembelajaran.

\section{II.METODE PENELITIAN}

Sampel Penelitian

Sampel yang digunakan dalam penelitian ini adalah Mahasiswa Program Studi Pendidikan Kimia Unram Tingkat I yang telah/sedang mengambil matakuliah Kimia Dasar I dengan jumlah 35 orang

\section{Persiapan Penelitian}

Persiapan penelitian berupa: pembuatan skenario pembelajaran, materi pembelajaran, alat ukur tes/soal berdasarkan kisi-kisi, dan lembar analisis data hasil penelitian

\section{Pelaksanaan Penelitian}

Pelaksanaan penelitian mengacu pada peneliti terdahulu [9], yaitu melalui tahapan: (1) Pelaksanaan pembelajaran topik Kesetimbangan Kimia sebanyak 4 kali pertemuan sesuai GBPP di Progdi. Pend. Kimia FKIP Unram, (2) Pelaksanaan Tes: Tes yang digunakan berupa soal uraian yang telah dinyatakan valid oleh Kousathana dan Tsaparlis [10]. Soal tersebut mengandung beberapa konsep esensial sebagaimana tercantum dalam tebale 1 . 
Tabel 1. Konsep Esensial dalam Topik Kesetimbangan Kimia Analsis Data

\begin{tabular}{ll}
\hline \multicolumn{2}{l}{ Aspek yang diukur } \\
\hline 1. & Konsep mol dan stoikhiometri \\
2. & Konsentrasi dan tetapan kesetimbangan \\
3. & Arah reaksi bila terjadi gangguan kesetimbangan/prinsip Le Chatelier pada \\
& kesetimbangan heterogen \\
4. & Hukum gas ideal dan kesetimbangan reaksi fasa gas \\
\hline
\end{tabular}

Data hasil penelitian terdiri dari data kuantitatif dan kualitatif: (1) Data kuantitatif: berupa jenis kesalahan siswa pada kelima aspek tersebut berdasarkan persentase siswa yang menjawab salah [10] dan disajikan dalam bentuk tabel. (2) Kualitatif: berupa kemungkinan penyebab kesalahan yang diungkap berdasarkan analisis jawaban siswa yang menjawab salah pada setiap aspek dan dijelaskan secara naratif.

\section{HASIL DAN PEMBAHASAN}

Penelitian ini bermaksud mengkaji/mendiagnosis kesalahan konsep mahasiswa dalam memahami konsep kesetimbangan kimia. Analisis kesalahan konsep didasarkan pada cara Niaz [2]. Dalam penelitian ini kesalahan konsep mahasiswa pada topik kesetimbangan difokuskan pada lima aspek yang cukup kompleks yaitu: (1) konsep mol dan stoikhiometri, (2) konsentrasi dan tetapan kesetimbangan, (3) reaksi fasa gas dan hukum gas ideal dan (4) arah reaksi bila terjadi gangguan sistem setimbang/prinsip Le Chatelier pada kesetimbangan heterogen. Permasalahan yang diberikan pada mahasiswa tercantum pada tabel 2.

Tabel 2. Tes Kemamapuan Mahasiswa dalam Topik Kesetimbangan Kimia

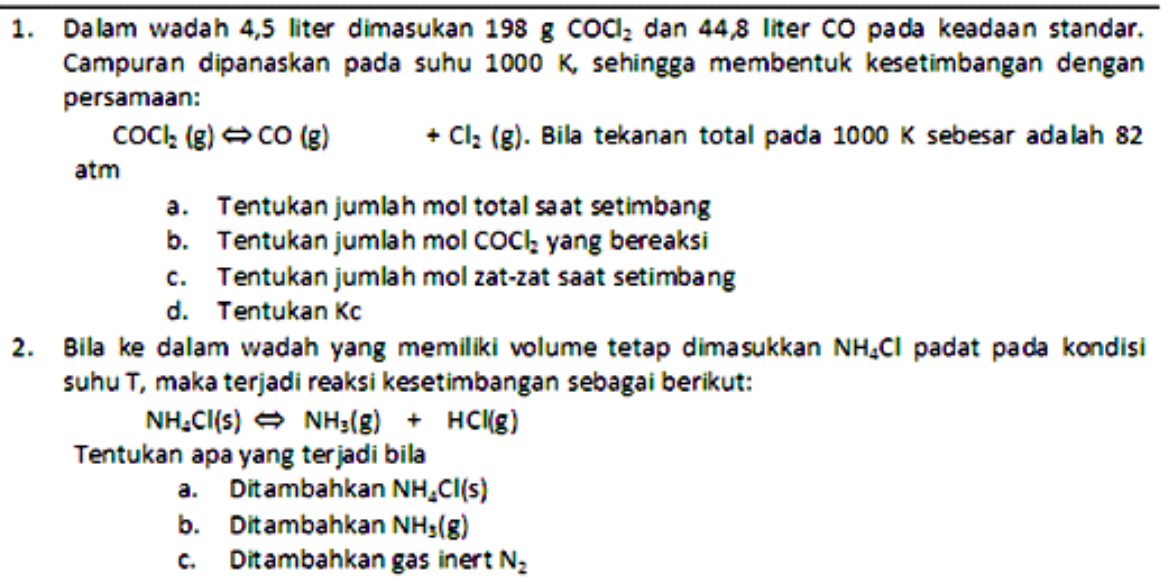

Dari permasalahan atau tes yang diberikan kepada 35 mahasiswa, maka dapat diperoleh informasi bahwa kesalahan konsep mahasiswa dalam menjawab pertanyaan tersebut dapat digolongkan menjadi beberapa jenis sebagaimana tercantum dalam tabel 3.

Tabel 3. Kesalahan Konsep Mahasiswa pada Pemasalahan Kesetimbangan Kimia

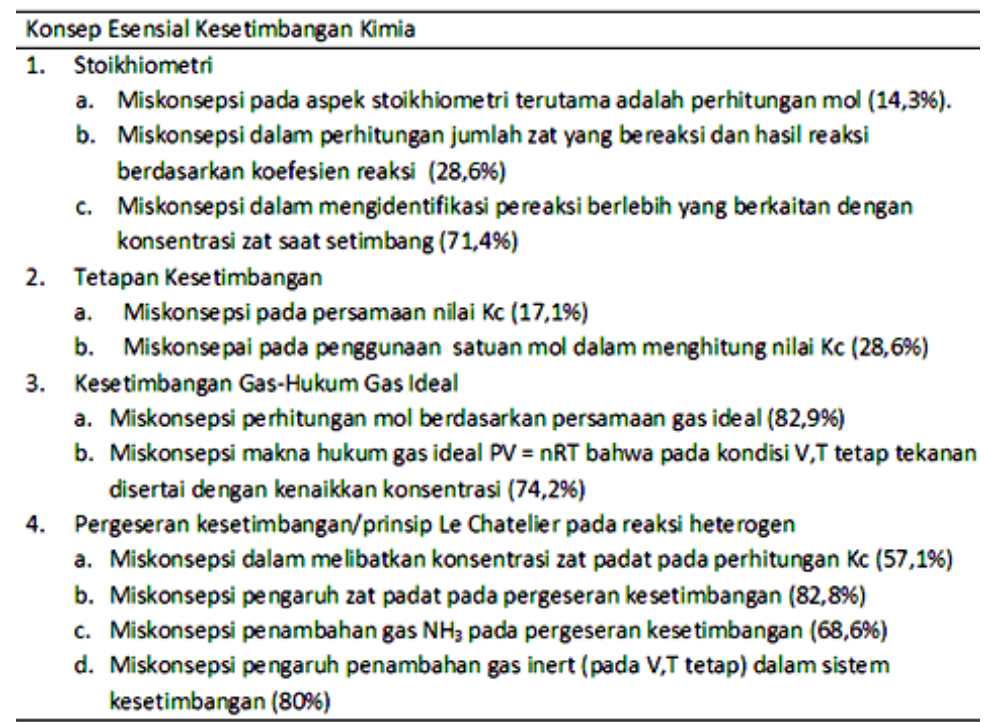




\section{Kesalahan Konsep Mahasiswa pada Stoikhiometri}

Kesalahan konsep mahasiswa pada konsep stoikhiometri cukup rendah, yaitu sekitar 14,3\%, terutama pada bagian perhitungan mol. Dalam hal ini ada beberapa mahasiswa yang tidak melakukan konversi dari gram maupun liter ke jumlah mol. Sebagaimana tercantum pada permasalahan/soal nomor 1, maka dari 14,3\% mahasiswa langsung menggunakan satuan gram dan liter. Kesulitan dalam perhitungan mol pada permasalahan kesetimbangan kimia juga sama dengan hasil penelitian yang dilakukan oleh peneliti terdahulu [12][13][14].

Kesalahan konsep mahasiswa dalam perhitungan jumlah zat yang bereaksi dan hasil reaksi cukup tinggi, yaitu 28,6\%. Namun kesalahan ini dapat diduga akibat dari tidak adanya penguasaan konsep pada persamaan gas ideal PV = nRT. Mahasiswa juga tidak memanfaatkan data nilai volume yang besarnya 4,5 liter, sehingga tidak dapat menghitung mol total. Akibat ketidakmampuan dalam memahami persamaan gas ideal, maka mahasiswa menggunakan pemisalan dengan derajat disossiasi a. Penggunaan a diduga akibat kebiasaan mahasiswa saat melakukan perhitungan dalam reaksi kesetimbangan.

Ditemukan juga adanya jawaban yang benar dalam menghitung jumlah mol total, tetapi pada saat perhitungan zat-zat yang terlibat dalam reaksi mengalami miskonsepsi sebagai berikut:

Dari hasil analisis tersebut menunjukkan bahwa mahasiswa menggunakan angka 2a untuk zat yang bereaksi. Akibatnya mahasiswa melakukan perhitungan yang rumit untuk mencari a melalui persamaan Kc. Semestinya mahasiswa langsung menggunakan jumlah mol zat yang bereaksi. Kesalahan konsep mahasiswa dalam memahami stoikhiometri juga ditemukan oleh peneliti terdahulu [12]

Definisi konsentrasi berlebih pada sistem kesetimbangan adalah jumlah mol yang tidak bereaksi (bagi pereaksi) atau jumlah mol yang dihasilkan pada reaksi kimia (bagi hasil reaksi). Apabila produk reaksi sudah ada sebelum keadaan setimbang terjadi, maka konsentrasi setimbang adalah konsentrasi zat yang dihasilkan oleh reaksi dan zat yang ada sebelum reaksi berlangsung (tabel 4 berisi jawaban soal nomor 1 yang benar).

Kesalahan Konsep Mahasiswa pada Ungkapan

\section{Tetapan Kesetimbangan}

Dari hasil analisis jawaban siswa, ditemukan beberapa kesulitan cukup rendah dalam menghitung persamaan Kc pada reaksi tersebut, yaitu kira-kira 17,1\%. Kekeliruan hanya pada penempatan zat yang bereaksi dan produk dimana sebagian kecil mahasiswa masih terbalik dalam menuliskan ungkapan Kc.

Kesalahan mahasiswa dalam menyatakan konsentrasi pada rumus Kc adalah belum mengkonversi satuan mol menjadi molar. Berikut ini diberikan contoh miskonsepsi siswa untuk kasus pada soal tersebut, yaitu $K c=\frac{[c 0]\left[\mathrm{Cl}_{2}\right]}{\left[\mathrm{COCl}_{2}\right]}=\frac{(2,5)(0,5)}{(1,5)}=0,83$

Tabel. 4. Jawaban Soal Nomor 1

\section{Reaksi Kesetimbangan yang Melibatkan Hukum Gas Ideal}

Reaksi kesetimbangan yang dibahas pada mahasiswa tingkat dasar pada umumnya adalah reaksi fasa gas. Oleh sebab itu variabel keadaan bagi gas ideal, yaitu mol n, suhu T, tekanan P dan volume V serta tetapan gas R perlu diperhatikan. Persamaan yang menghubungkan variabel tersebut disebut dengan persamaan keadaan gas ideal, yaitu $P V=n R T$. Akan tetapi dalam kenyataannya pemahaman mahasiswa pada konsep gas ideal masih rendah. Hal ini terbukti bahwa pada saat ada permasalahan yang berkaitan dengan gas ideal ditemukan hampir $80 \%$ mahasiswa mengalami kesulitan.

Miskonsepsi siswa dalam pemahaman gas ideal juga terjadi pada siswa yang digolongkan bentuk kesalahan kesalahan konsep [10]. Namun menurut pendapat Furio dan kawan kawan menyatakan sebagai kesalahan acak, yaitu merupakan kesalahan yang berhubungan dengan ketidaktahuan (memang benar tidak tahu), kelelahan pikiran, dan kecerobohan dalam menyelesaikan soal [5]. Berdasarkan permasalahan yang tercantum dalam tabel 5, maka dapat dilakukan analisis sebagai berikut

\section{Tabel 5. Permasalahan Hukum Gas Ideal}

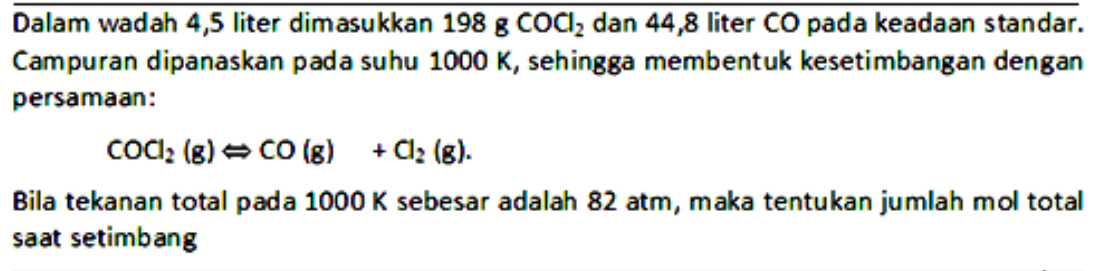


Berdasarkan hasil analisis jawaban mahasiswa, maka sebagian besar mahasiswa (80\%) tidak mengunakan hukum gas ideal, tetapi terfokus pada data massa $\mathrm{COCl}_{2}$, volume $\mathrm{CO}$ dan menyusun persamaan reaksi kesetimbangan yang melibatkan unsur zat mula-mula, zat yang bereaksi, derajat disossiasi, dan jumlah zat saat setimbang. Hal ini diduga menggunakan kebiasaan dari apa yang dilakukan pada saat di SMA. Hasil penelitian ini disebut sebagai kesalahan konsep sebagaimana dinyatakan oleh Furio dan kawan-kawanm yang menerangkan kesalahan konsep tersebut dibangun sesuai yang mereka alami [5]

Sebagian kecil mahasiswa yang memikirkan bahwa untuk gas terdapat hubungan antara mol n, tekanan $\mathrm{P}$, volume $\mathrm{V}$ dan suhu $\mathrm{T}$ dalam persamaan $\mathrm{PV}=\mathrm{nRT}$, sehingga diperoleh: Jumlah mol total saat setimbang $P V=n R T$ atau $n=\frac{P V}{R T}=82 \times \frac{4,5}{0,082 \times 1000}=4,5 \mathrm{~mol}$. Kesalahan konsep siswa dalam menerapkan hukum gas ideal dalam sistem kesetimbangan juga telah dilaporkan oleh Solaz dan Juan Quilez [11].

\section{Pergeseran kesetimbangan prinsip Le Chatelier pada reaksi heterogen}

Kesalahan konsep mahasiswa dalam memahami prinsip pergeseran kesetim-bangan/prinsip Le Chatelier pada reaksi heterogen sebagaimana tercantum pada tabel 1 dan penyelesainnya disajikan dalam tabel 6 berikut.

Tabel 6. Jawaban Permasalahan Prinsip Le Chatelier

Untuk reaksi kesetimbangan $\mathrm{NH}_{4} \mathrm{Cl}(\mathrm{s}) \Leftrightarrow \mathrm{NH}_{5}(g)+\mathrm{HCl}(g)$, maka

a. Penambahan zat padat $\mathrm{NH}_{4} \mathrm{Cl}(\mathrm{s})$ dalam kondisi setimbang tidak mempengaruhi kesetimbangan, karena kesetimbangan hanya dipengaruhi zat fasa gas dan aktivitas fasa padat selama kondisi setimbang adalah tetap.

Penambahan gas $\mathrm{NH}_{5}(g)$ pada kondisi $\mathrm{V}, T$ tetap dalam kondisi setimbang, maka akan terjadi reaksi pembentukan $\mathrm{NH}_{4} \mathrm{Cl}$ atau reaksi kearah kiri atau terjadi pergeseran kesetimbangan ke arah kiri

. Penambahan gas inert $N_{2}$ pada $V, T$ tetap dalam sistem setimbang akan berpengaruh pada tekanan total (Qulilez-Pardo dan Solaz-Portoles, 1995). Oleh sebab itu menurut prinsip le Chatelier akan terjadi aksi yaitu reaksi yang mengarah pada penurunan jumlah molekul yang dalam hal ini adalah reaksi pembentukan $\mathrm{NH}_{4} \mathrm{Cl}$. Dengan demikian terjadi pergeseran kearah kiri.

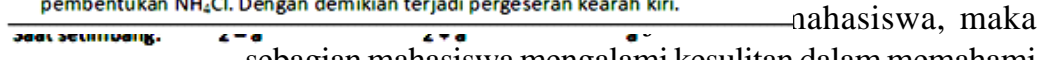
Total mol zat saat setimbsẹp.

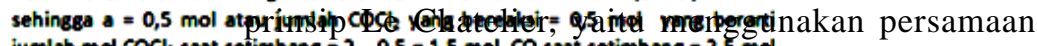

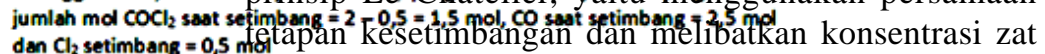

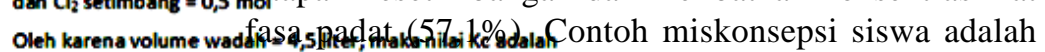
menggunakan jawaban dengan persamaan

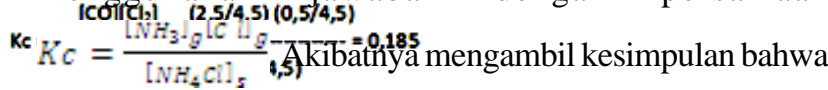
pada penambahamzat padat pada sistem setimbang maka reaksi akan bergeser ke kiri. Miskonsepsi tersebut diduga dalam memahami pronsip Le Chatelier, mereka menggunakan persamaan kesetimbangan, yaitu bila Kc'< Kc akan bergeser ke arah pembilang dan sebaliknya [5]. Oleh sebab itu dalam penelitian miskonsepsi siswa mencapai 82,8\%.

Berdasarkan jawaban siswa dapat diduga bahwa kesalahan tersebut akibat belum memahami arti kesetimbangan heterogen dimana nilai $\mathrm{K}$ sebanding dengan perkalian aktivitas zat pada fasa gas dan nilainya hanya dipengaruhi oleh suhu. Hasil penelitian ini juga didukung oleh hasil penelitian terdahulu [4],[7],[10]
Pengaruh penambahan gas $\mathrm{NH}_{3}$ akan menggeser kesetimbangan ke arah kiri, miskonsepsi sekitar 68,6\% dan tidak satupun yang mampu menjelaskan bahwa akibat penambahan jumlah $\mathrm{NH}_{3}$ juga akan menurunkan jumlah tekanan parsial HCl. Hal ini menunjukkan bahwa mereka belum memahami bahwa bergesernya reaksi ke kiri pada dasarnya terjadi reaksi pembentukan $\mathrm{NH}_{4} \mathrm{Cl}$

Penambahan gas iner $\mathrm{N}_{2}\left({ }_{\mathrm{V}, \mathrm{T} \text { tetap }}\right)$ pada sistem kesetimbangan tidak mengalami reaksi kimia, tetapi akan meningkatkan tekanan total hal ini sesuai dengan hukum gas ideal [7]. Pertanyaan ini menguji kemampuan mahasiswa dalam memahami hukum gas ideal (Soal 3b.) dan pergeseran kimia yang melibatkan gas iner. Berdasarkan hasil analisis jawaban soal 3b, maka miskonsepsi siswa cukup besar yaitu mencapai $74,2 \%$. Menurut prinsip Le Chatelier bila suatu sistem berada dalam keadaan setimbang, adanya gangguan pada beberapa faktor yang mempengaruhi keadaan setimbang, maka kesetimbangan akan bergeser kearah yang dapat memperkecil gangguan tersebut. Oleh sebab itu dengan adanya peningkatan tekanan total, maka agar sistem tetap setimbang harus berusaha mengurangi jumlah molnya atau menuju ke arah jumlah molekul kecil (ke kiri) [7],[11],[13]

\section{IV.KESIMPULANDANSARAN \\ Kesimpulan}

Kesimpulan yang diperoleh dari penelitian ini adalah sebagai berikut

1. Hasil analisis miskonsepsi mahasiswa pada empat konsep esensial kesetimbangan kimia ditemukan sebesar $30,10 \%$ mahasiswa yang mengalami miskonsepsi pada konsep mol dan stoikhiometri, $22,85 \%$ pada konsep tetapan kesetimbangan, 78,55\% pada konsep kesetimbangan yang melibatkan gas ideal, dan 70,78\% pada konsep pergeseran kestimbangan/ prinsip Le Chatelier's pada reaksi heterogen.

2. Miskonsepsi pada aspek stoikhiometri terutama adalah kegagalan dalam mengkonversi hubungan gram-molliter $(14,3 \%)$, perhitungan zat-zat yang terlibat dalam reaksi (28,6\%) dan mengidentifikasi pereaksi berlebih (71,4\%)

3. Miskonsepsi pada aspek tetapan kesetimbangan adalah pernyataan persamaan Kc $(17,1 \%)$, penggunaan satuan mol dalam menghitung nilai Kc (28,6\%)

4. Miskonsepsi pada aspek kesetimbangan yang melibatkan gas ideal adalah kegagalan dalam menghitung jumlah mol berdasarkan persamaan gasmenghitung ideal $P V=n R T \quad(82,9 \%)$, dan mengartikan hukum tersebut (74,2\%)

5. Miskonsepsi pada aspek pergeseran kesetimbangan/ prinsip Le Chatelier's adalah melibatkan zat padat pada perhitungan Kc $(57,1 \%)$, pengaruh zat padat pada kesetimbangan (82,8\%), pengaruh gas $\mathrm{NH}_{3}(68,6 \%)$, dan pengaruh gas iner $\mathrm{N}_{2}$ padfa $\mathrm{V}$, T tetap sebesar $80 \%$

\section{Saran}

Saran yang disampaikan dari hasil penelitian ini adalah sebagai berikut: mengingat bahwa adanya kesalahan konsep mahasiswa dalam memahami konsep 
kesetimbangan kimia maka diperlukan upaya strategi/ metode pembelajaran yang dapat mengatasi kesalahan konsep tersebut.

\section{DAFTAR PUSTAKA}

[1] Mulford D.R dan Robinson W.R. 2004. An Inventory for Alternate Conceptions among. First-Semester General Chemistry Students. J. Chem. Educ, 79: 739 -744 .

[2] Niaz, M. (2001). Response to contradiction: Conflict resolution strategies used by students in solving problems of chemical equilibrium. Journal of Science Education and Technology, 10, 205-211.

[3] Bergquist, W. dan Heikkinen, H. 1990. Student ideas regarding chemical equilibrium. Journal of Chemical Education, 67 (12): 1000 - 1003

[4] Tyson, L, Treagust, D.F., dan Bucat, R.B. 1999. The complexity of teaching and learning chemical equilibrium. Journal of Chemical Education, 76,: $554-558$

[5] Furio, C., Calatayud, M.L., Barcenas, S.I., \& Padilla, O.M. (2000). Functional fixedness and functional reduction as common sense reasoning in chemical equilibrium and in geometry and polarity of molecules. Science Education, 84, 545-565.

[6] Banerjee, A.C. 1991. Misconceptions of student and teachers in chemical equilibrium. International of Journal of Science Education, 13: 487 - 494

[7] Quilez-Pardo, J. dan Solaz-Portolez, J.J. 1995. Student's and teachers misconception of Le Chatelier's principles: Implications for teaching of chemical equilibrium. Journal Research in Science Teaching, 12: $939-957$

[8] Huddle, P.A. dan Pillay, A.E. 1996. An in-dept study of misconceptions in stoikhiometry and chemical equilibrium at a South African University. Journal of Research in Teaching. 33: 65 - 77)

[9] Tyson, L., Treagust, D.F., \& Bucat, R.B. (1999). The complexity of teaching and learning chemical equilibrium. Journal of Chemical Education, 76, 554558.

[10] Kousthanaa, M. dan Tsaparlis, G. 2006. Student's errors in solving numerical chemical equilibrium problems. Chemistry Education: Research and Practice in Europe, Vol. 3, No. 1: 5 - 17

[11] Solaz, J.J. \& Juan Quilez, J. (2001). Changes of extent of reaction in open chemical equilibria.Chemistry Education: Research and Practice in Europe (CERAPIE), 2, 303-312.[http://www.uoi.gr/conf_sem/ cerapie]

[12] Camaco, M. dan Good, R. 1989. Problem solving and chemical equilibrium: Successful versus unsuccessful performance. Journal of Research in Science Teaching, 26: $251-272$
[13] Pedrosa, M.A. \& Dias, M.H. (2000). Chemistry textbook approaches to chemical equilibrium and student alternative conceptions. Chemistry Education: Research and Practice in Europe(CERAPIE), 1, 227-236. [http://www.uoi.gr/ conf_sem/cerapie]

[14] Maskill, R. \& Cachapuz, A.F.C. (1989). Learning about the chemistry topic of equilibrium: The use of wordassociation tests to detect developing conceptualism. International Journal of Science Education, 11, 57-69. 